\title{
THE USE OF PLATELET-RICH FIBRIN COMBINED WITH FREE GINGIVAL GRAFT IN THE MANAGEMENT OF INSUFFICIENT ATTACHED GINGIVA AT TEETH WITH GINGIVAL RECESSION
}

\author{
Ahmed Elsayed Hamed Amr*
}

\begin{abstract}
Aim: This study was carried to evaluate the effect of the placement of PRF membrane beneath the free gingival graft in gingival augmentation surgeries regarding the changes by time in graft horizontal dimension, vertical dimension and total surface area.

Subjects and Methods: Sixteen patients were selected. All the patients showed gingival recession with insufficient attached gingiva. The gingival augmentation surgery was decided to be performed as a primary surgery to increase the attached gingiva with no attempt to cover the recession during this study. Group 1 (test group) included eight patients where the gingival augmentation was performed using a free gingival graft in combination with a platelet rich fibrin membrane placed beneath the graft at the recipient site. Group 2 (control group) included eight patients where the gingival augmentation was performed using a free gingival graft only. The graft vertical dimension (GVD) and the graft horizontal dimension (GHD) were measured using William's graduated periodontal probe. Plaque index, gingival bleeding index and probing depth were used to monitor the oral hygiene status and gingival health condition throughout the study. All the measures were obtained at 2 occasions; the day of the surgery and 1.5 months after the surgery.
\end{abstract}

Results: Regarding the changes in GVD, a statistically significant greater mean and median percent decrease was noted in group 2 after 1.5 month. The same was obtained with the changes in GHD and graft surface area.

Conclusion: Using platelet-rich fibrin beneath free gingival graft in gingival augmentation surgery resulted in successful increase in the attached gingiva with less dimensional changes by time in the transplanted free gingival graft compared to using free gingival graft alone.

\section{INTRODUCTION}

The attached gingiva represents only part of the keratinized gingiva extending from the free gingival groove till the mucogingival junction while the keratinized gingiva extends from the gingival margin till the mucogingival junction (Joshi et al., 2016)

\footnotetext{
* Lecturer of Oral Medicine and Periodontology, Faculty of Dentistry, Ain Shams University
} 
Although many studies showed that at least 1 $\mathrm{mm}$ of attached gingiva is necessary to maintain healthy periodontium, other studies believed that the exact amount of attached gingiva necessary for healthy periodontium is controversial. ( Gargiulo et al.,1961; Dorfamn et al., 1980; Dorfman et al., 1982; Ericsson\&Lindhe, 1984; Kennedy et al., 1985; Nevins et al., 1986; Wennstrom, 1987; Freedman et al., 1999).

Some authors showed that the presence of moveable alveolar mucosa only without attached gingiva may be kept healthy for a long period when the patient oral hygiene and plaque control measures were well performed (Kisch et al., 1986; Salkin et al., 1987). Other authors proved that teeth with narrow zone of attached gingiva suffers higher inflammatory and recession indices than teeth with enough amount of attached gingiva believing that the wide attached gingiva better withstands trauma from mastication and tooth brushing and better resists gingival inflammation and pulling forces of the muscles.(Wennstrom et al., 1983; Ericsson \&Lindhe, 1984; Stetler \& Bissada, 1987)

Long tapered teeth are more susceptible to gingival recession when compared to square shaped teeth since wider zone of attached gingiva is usually associated with the square shaped teeth (Weisgold, 1977; Olsson et al., 1993). The gingival biotype commonly known as being thick or thin (Weisgold, 1977), has been recently classified as thin scalloped, thick flat or thick scalloped.( De Rouck et al.,2009; Eghbali et al., 2009). It can be measured via direct visual assessment,ultrasonic devices and Cone beam computed tomography while the most applicable commonly used method is the probe transparency through the gingiva (Greenberg et al., 1976; Muller et al., 2000; Barriviera et al., 2009;; Stein et al., 2013). Studies concluded that thin scalloped biotype is associated with narrow zone of attached gingiva and is subjected to higher risk of gingival recession compared to thick flat biotype (Olsson et al., 1993; Anderegg et al., 1995; Baldi et al., 1999; Pontoriero \& Carnevale, 2001; Hwang and Wang, 2006; Gobbato et al., 2012)

Wilson in 1983 monitored teeth with inadequate attached gingiva \&showed that they were subjected to mucogingival defects and further recession (Wilson, 1983). Surgical augmentation of the attached gingiva improves patient comfort and facilitates the control of dental plaque (Lindhe et al., 1996). Long term studies showed that gingival augmentation procedures helped in avoiding gingival recession overtime (Agudio et al., 2008; Agudio et al., 2009)

Free gingival autografts (FGG) is considered simple, easy, highly predictable gingival augmentation modality. The free gingival autograft first described by Bjorn in 1963 and Sullivan \&Atkins in 1968 has been used to increase the zone of attached gingiva, deepen the vestibule and in treatment of gingival recession (Bjorn, 1963; Sullivan \& Atkins, 1968; Holbrook \& Ochsenbein, 1983; Miller, 1985). The most common site for harvesting the FGG is the palate in the zone between the canine and the first molar palatal root .The greater and lesser palatine nerves \& blood vessels should be avoided during graft harvesting .They enter the palate through the greater and lesser palatine foramina close to the third molar and pass across the palate into the incisive foramen. Usually, they are located 7-17 $\mathrm{mm}$ from the CEJ of upper premolars and molars being closer to the CEJ in shallow palatal vaults (Reiser et al., 1996). The palatal rugae area should not be included in the graft since it may lead to poor esthetic results and will keep its morphology permanently (Cohen, 1994; Breault et al., 1999)

The thickness of the palatal graft should range from $0.75-1.5 \mathrm{~mm}$ to make sure that adequate amount of connective tissue has been included in the graft. This was based upon the fact that the mean thickness of the palatal epithelium is 
0.34 mm. (Soehren, 1973; Carranza, 1976; Goldman et al., 1976; Camarago et al., 2001)

It should be noted that thicker grafts may end up with unaesthetic results in addition to deep palatal donor site, while thin grafts are associated with ideal color matching and accepted esthetic outcomes. (Sullivan and Atkins, 1968; Brackett \& Gargiulo, 1970; Lampert et al., 1976). Moreover thin grafts revascularize and heal faster than thicker grafts since thick connective tissue shows greater primary contraction, collapse of blood vessels and delayed revascularization (Sullivan \& Atkins, 1968; Camargo et al., 2001)

During the first day after grafting and before the revascularization of the graft, the graft is totally dependent on plasmic circulation from the recipient bed (Forman, 1960; Reese \& Stark, 1961). Capillaries proliferation into the graft starts by day 2 after the surgery and sufficient blood supply appear by day 8 . The connective tissue union between the graft and bed start by day 4 and is completed at day 10 and may be responsible for some of the contraction of the graft.(Davis \& Traut, 1925; Egli et al., 1975)

Many studies proved that the transplanted tissue showed changes in the horizontal and vertical dimensions over time after grafting and especially during the first postoperative month. (Ericsson 1984; Hatipoglu et al 2007). The shrinkage of the free gingival graft is about $32 \%-45 \%$ and most of the graft shrinkage has been shown to occur during the first year after surgery then the dimensions stabilized (Dreeskamp \& de Jacoby, 1973; Soehren et al., 1973; Ward, 1974; Egli et al., 1975; James and Mc Fall, 1978; Rateitschak, 1979; Orsini et al., 2004; Barbosa et al., 2009). Many authors proved that the graft shrinks vertically more than horizontally. (Orsini et al., 2004; Hatipoglu et al., 2007)

Platelet-rich fibrin (PRF) is a platelet concentrate with leukocytes in a dense fibrin matrix. It is an autogenous material prepared by centrifuging the patient's own non-anticoagulated blood (Choukroun and Diss, 2006). PRF is considered second generation of platelets concentrates and an improved formulation of the traditional platelet-rich plasma (PRP). (Choukroun et al., 2001; Dohan Ehrenfest et al., 2010). PRF was introduced in France by choukroun et al., in 2001. The patient's whole non-anticoagulated blood is immediately centrifuged after withdrawal from the patient resulting in PRF in short period of time (Choukroun et al.,2001; Simonpieri et al.,2009). Being prepared without adding anticoagulant to the blood samples, the PRF can be considered purely autologous. The fibrin matrix obtained is rich in platelets, leukocytes and many growth factors including transforming growth factor beta 1 (TGF- $\beta 1$ ), vascular endothelial growth factor (VEGF), interleukin beta (IL-1 $\beta$ ), platelet derived growth factor PDGF, IL-4, IL-6. (Dohan et al., 2006). The L-PRF membrane is modified PRF to contain most of the platelets and leukocytes present in the blood plus the platelet growth factors and stem cells that are also trapped within the fibrin network with enhanced strength (Dohan Ehrenfest 2018).

The original idea behind platelet concentrates is that concentrated platelets and autologous growth factors are collected in a structure that can be used to enhance cellular migration, adhesion \& proliferation at the surgical sites thus promoting rapid organization of the tissues and early healing. (Anfossi et al., 1989; Fijnheer et al., 1990; Whitman et al., 1997; Marx et al., 1998; Marx, 2004; Dohan \& Choukroun, 2006 ; Jameson, 2007; Kutkut \& Andreana, 2012)

Since the recipient site healing following the free gingival grafts is a complicated mechanism as discussed above and depends initially on the plasmic circulation which requires excellent free gingival graft adaptation and stabilization at the recipient site. Moreover, since postoperative graft shrinkage is an inevitable process according to 
previous literature. Thus, FGG combined with PRF in augmentation of attached gingiva by placing the PRF membrane beneath the FGG may have a beneficial effect on healing since PRF is rich in many critical factors that may aid healing and may improve the final grafting outcomes.

\section{AIM OF THE STUDY:}

This study was carried to evaluate the effect of the placement of PRF membrane beneath the free gingival graft in gingival augmentation surgeries regarding the changes over time in graft's horizontal dimension, vertical dimension and total surface area.

\section{SUBJECTS AND METHODS:}

Sixteen patients were selected from the outpatients' clinic of the department of Oral medicine and periodontology, faculty of dentistry, Ain Shams University.

All the patients showed gingival recession (class 1 or 2, Miller 1985) at two lower anterior neighboring teeth with insufficient attached gingiva $<1 \mathrm{~mm}$ and thin gingival biotype $\leq 1 \mathrm{~mm}$. The gingival augmentation surgery was decided to be performed as a primary surgery to increase the attached gingiva with no attempt to cover the recession during this study.

All the patients included in the study were free from any systemic diseases as evidenced by Burket's oral medicine health history questionnaire (Glick et al., 2008), age range 30-45, nonsmokers. Any patients with mobility, crowding or subgingival restorations in the lower anteriors were excluded from the study. Any patients with probing depth $\geq 2 \mathrm{~mm}$ were excluded from the study. Patients with palatal abnormalities or anatomic variations and patients who did not follow the oral hygiene instructions for proper plaque control after the conventional periodontal therapy were also excluded from the study. Roll technique was applied to determine the keratinized tissue width 2 weeks after initial periodontal treatment.
Patients were randomly divided in 2 groups. Group 1 (test group) included eight patients where the gingival augmentation was performed using a free gingival graft (FGG) in combination with a platelet rich fibrin (PRF) membrane. The PRF membrane was placed beneath the FGG at the recipient site. Group 2 (control group) included eight patients where the gingival augmentation was performed using a free gingival graft only. All the patients were informed about the full details of the surgery and an informed consent was taken.

\section{Treatment protocol}

Conventional periodontal treatment was performed to all patients two weeks before the surgical procedure and oral hygiene instructions were given. Preoperative photographs and periodontal measures (plaque index, gingival bleeding index, probing depth) were performed the day of the surgery just before starting the procedure.

\section{Surgical steps: (Figure 1)}

\section{Preparation of the Leukocyte Platelet-Rich Fi- brin (L-PRF) (for group 1 only):}

Blood was collected in 9ml glass-coated plastic tube and then rapidly (before $1 \mathrm{~min}$ ute) centrifuged at room temperature (2700 rpm for 12 minutes) producing L-PRF clot. The clot was placed in the sterile adapted surgical box and compressed into a membrane to be used later beneath the free gingival graft (Corso et al., 2010, Dohan Ehrenfest et al., 2018)

\section{Preparation of the recipient site (for both groups)}

After the administration of local anaesthesia to the recipient site (Articaine hydrochloride $4 \%$ with 1/100000 epinephrine, septanest SP, Septodont), Horizontal incision was performed below the gingival recession at the mucogingival junction using the scalpel with no 15-c blade. The horizontal 
incision should extend one tooth mesial and distal to the defect. Two vertical incisions were performed at the end of the horizontal incisions extending into the alveolar mucosa beyond the mucogingival junction (MGJ).

Partial thickness flap was dissected using the scalpel (blade 15c) starting at the apical portion of the vertical incision in apicocoronal fashion leaving the periosteum on the alveolar bone. The partial-thickness flap was displaced apically enough. Special care was taken during reflection in order to dissect as much as possible close to the periosteum to be sure that the epithelium, connective tissue and muscles were elevated thus recipient bed without moveable soft tissues was present which ensures that the free gingival graft later on will be stable during healing. The partial thickness flap was then sutured with interrupted sutures to the periosteum apically (polypropylene 4/0 interrupted suturesblue monofilament, Assut sutures). Measurement of the denuded recipient area vertically and horizontally was performed using the periodontal probe to prepare the suitable size of free gingival graft.

Graft harvesting from the palate (donor site) (for both groups):

The free gingival graft (FGG) was harvested with a scalpel (blade 15c) from the hard palate opposite to the premolars region according to the measurement of the recipient site. The FGG rectangular outline was performed by the scalpel not reaching the palatal bone then the FGG was dissected with the scalpel used parallel to the outer surface of the graft. The graft obtained was thinned using sharp curved scissors to obtain a uniform graft thickness around $1.5 \mathrm{~mm}$ thickness. Graft suturing at the recipient site (polypropylene 4/0 interrupted sutures- blue monofilament, Assut sutures) was then performed starting with interrupted sutures to the neighbouring teeth attached gingiva mesially and distally securing the graft at the recipient bed. Single intra- periosteal cross over suture was then performed aimed to immobilize the graft and achieve better adaptation. For group 1only (test group), the formerly prepared PRF membrane was placed beneath the sutured FGG after the interrupted sutures and before performing the cross over suture. For both groups, after performing the cross over suture, gentle firm pressure with gauze was applied for 5 minutes over the graft to displace any blood below the graft ensuring graft adaptation, stabilization and minimal blood clot thickness and rapid revascularization. Finally, the palatal wound in both groups is covered by a small piece of PRF
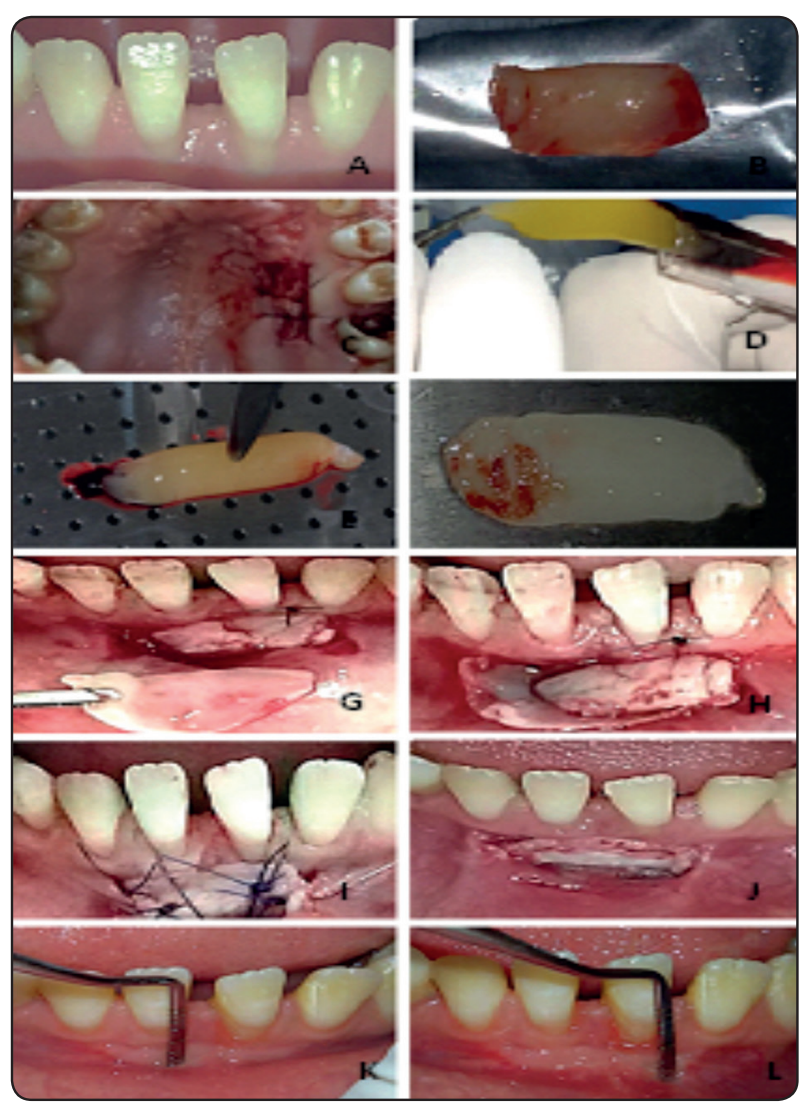

Fig. (1) A-L Free gingival graft combined with PRF surgical procedure. A: Lower incisors lack attached gingiva. $B, C$ : Free gingival graft harvested from the hard palate. D, E, F: preparation of the PRF membrane. G, H: PRF membrane placed beneath the free gingival graft at the recipient site. I: suturing of the free gingival graft. J: recipient site 10 days after surgery. $\mathrm{K}, \mathrm{L}$ : recipient site 1.5 month after surgery. 
membrane stabilized by horizontal matress suture.

For both groups, postoperative medications were prescribed [amoxicillin $875 \mathrm{mg} /$ clavulanic acid $125 \mathrm{mg}$ - orally 1 tablet every 12 hours for 7 days (Hibiotic 1gm tablets/ Amoun Pharmaceuticals) and dexamethasone phosphate $8 \mathrm{mg}$ I.M. single injection (Epidron ampoule 2ml; Eipico)] and the patients were advised to avoid brushing and flossing the surgical site and to use chlorhexidine HCL mouth wash three times daily until suture removal 10 days after the surgery.

\section{Evaluation and measures:}

The graft vertical graft dimension (GVD, apicocoronal measure) and the graft horizontal dimension (GHD, mesiodistal measure) were measured throughout the study to the nearest $\mathrm{mm}$ using William's graduated periodontal probe. Graft surface area (GSA) was obtained by multiplying the graft horizontal and vertical dimensions. Plaque index, gingival bleeding index and probing depth were used to monitor the oral hygiene status and gingival health condition throughout the study.

Plaque Index (PI) (Löe 1967) was scored as follows: 0: No plaque in gingival area, 1: No plaque visible by the unaided eye, but plaque is made visible on the point of the probe after it has been moved across surface at entrance of gingival crevice, 2: Gingival area is covered with a thin to moderately thick layer of plaque; deposit is visible to the naked eye, 3: Heavy accumulation of plaque within the gingival pocket and/or on the gingival margin and adjacent tooth surface. Sulcus Bleeding Index (BI) (Mühlemann \& Son 1971) scored as follows: 0: No inflammation, no bleeding on probing. 1: Bleeding from gingival sulcus on gentle probing; tissues otherwise appears normal, 2 : Bleeding on probing plus change in color due to inflammation, 3: Bleeding on probing plus change in color and slight edema, 4: Bleeding on probing, color change and obvious edema, 5: Spontaneous bleeding, color change and marked edema. Probing Depth (PD) (Glavind \& Löe 1967) was measured from the gingival margin to the base of the pocket to the nearest $\mathrm{mm}$.

All the previous measures were obtained in this study at 2 occasions; baseline and follow up. The baseline measures were obtained the day of the surgery. The bleeding index, plaque index and probing depth were performed before the surgery while measurement of the graft dimensions was performed after graft suturing. The follow up measures were obtained 1.5 months after the surgery. Regarding the measurements of the graft dimensions, for every patient at each occasion the vertical measure was performed at three points along the length of the graft; one mesial, one distal and one in the middle of the graft then the mean graft vertical dimension was calculated. The same was performed with the horizontal graft dimension, the horizontal measure was performed at three points; one coronal, one apical and one in the middle of the graft then the mean graft horizontal dimension was calculated.

\section{Statistical analysis}

Numerical data were explored for normality using Kolmogorov-Smirnov test of normality. Normally distributed (parametric data), were presented as mean, standard deviation (SD), minimum and maximum and were compared between groups using independent $t$ test (intergroup). Paired t test was used for intergroup comparison in different observation times. For non- parametric data, percent change groups were compared using Mann Whitney U test.

\section{RESULTS}

Probing depth, bleeding index and plaque index: In group I, Wilcoxon signed Rank test revealed no significant difference between baseline and 1.5 month values of PD, BI, PI ( $p=0.317$, 
$\mathrm{p}=0.317, \mathrm{p}=0.157$ respectively). In group II, Wilcoxon signed Rank test revealed no significant difference between baseline and 1.5 month values of PD, BI, PI ( $p=1, p=0.157, p=0.157$ respectively). The same median baseline PD, BI, PI values were recorded in both groups, with no significant difference as indicated by Mann Whitney test ( $\mathrm{p}=0.317, \mathrm{p}=1, \mathrm{p}=1$ respectively). The same median 1.5 month PD, BI, PI values were recorded in both groups, with no significant difference as indicated by Mann Whitney test $(\mathrm{p}=1, \mathrm{p}=0.591$, $\mathrm{p}=1$ respectively).

Graft vertical dimensions: In group 1, Mean value decreased from $(5.75 \pm 0.46)$ at baseline, to $(5.25 \pm 0.46)$ at 1.5 month. Paired t test indicated that the difference between baseline and 1.5 months was statistically significant $(\mathrm{p}=0.033)$, (Table 1, Fig.2). In group 2, Mean value decreased from $(5.75 \pm 0.46)$ at baseline, to $(3.75 \pm 0.71)$ at 1.5 month. Paired $t$ test indicated that the difference between baseline and 1.5 month was statistically significant ( $p=0.00)$, (Table 1, Fig.2). At baseline, there was no statistically significant difference between groups $(\mathrm{p}=1)$. At 1.5 month, a higher mean value was recorded in group 1 , with extremely significant difference ( $\mathrm{p}=0.00)$, (Table1, Fig.2)

Graft horizontal dimensions: In group 1, Mean value decreased from $(12.88 \pm 0.64)$ at baseline, to $(11.50 \pm 1.2)$ at 1.5 month. Paired $t$ test indicated that the difference between baseline and 1.5 month was statistically significant ( $\mathrm{p}=0.004)$, (Table 2, Fig.3). In group 2, Mean value decreased from $(13.38 \pm 0.52)$ at baseline, to $(9.63 \pm 0.52)$ at 1.5 month. Paired t test indicated that the difference between baseline and 1.5 month was statistically significant $(\mathrm{p}=0.00)$, (Table 2, Fig.3). At baseline, there was no statistically significant difference between groups $(\mathrm{p}=0.11)$. At 1.5 month, a higher mean value was recorded in group 1 , with a statistically significant difference ( $\mathrm{p}=0.00)$, (Table 2, Fig.3)

Graft Surface area: In group 1, Mean value
TABLE (1) Descriptive statistics of graft vertical dimension $(\mathrm{mm})$, intergroup comparison (independent $t$ test) and intragroup comparison (paired $t$ test)

\begin{tabular}{|c|c|c|c|c|c|}
\hline & Groups & Baseline & $\begin{array}{c}1.5 \\
\text { month }\end{array}$ & $\begin{array}{c}\text { Mean } \\
\text { difference }\end{array}$ & $\mathbf{P}$ \\
\hline & Mean & 5.75 & 5.25 & .50 & $.033^{*}$ \\
\hline & Std. Dev & .46 & .46 & & \\
\hline- & Std. Error & .16 & .16 & & \\
\hline$\overline{\bar{O}}$ & Median & 6.00 & 5.00 & & \\
\hline & Range & 1.00 & 1.00 & & \\
\hline & Min & 5.00 & 5.00 & & \\
\hline & Max & 6.00 & 6.00 & & \\
\hline & Mean & 5.75 & 3.75 & 2.00 & $0.00 *$ \\
\hline & Std. Dev & .46 & .71 & & \\
\hline $\mathrm{N}$ & Std. Error & .16 & .25 & & \\
\hline$\overline{\overline{0}}$ & Median & 6.00 & 4.00 & & \\
\hline & Range & 1.00 & 2.00 & & \\
\hline & Min & 5.00 & 3.00 & & \\
\hline & Max & 6.00 & 5.00 & & \\
\hline $\begin{array}{r}\text { I } \\
\text { cor }\end{array}$ & $\begin{array}{l}\text { tergroup } \\
\text { parison }(\mathrm{P})\end{array}$ & $1.00 \mathrm{NS}$ & $0.00 *$ & & \\
\hline $\mathrm{Me}$ & difference & 0.00 & 1.50 & & \\
\hline & $\begin{array}{l}\text { nfidence } \\
\text { terval of } \\
\text { fference }\end{array}$ & $\begin{array}{c}-.50 \text { to } \\
.50\end{array}$ & $\begin{array}{l}.85 \text { to } \\
2.15\end{array}$ & & \\
\hline
\end{tabular}

Significance level $p<0.05$, *significant, $n s=n o n$ significant

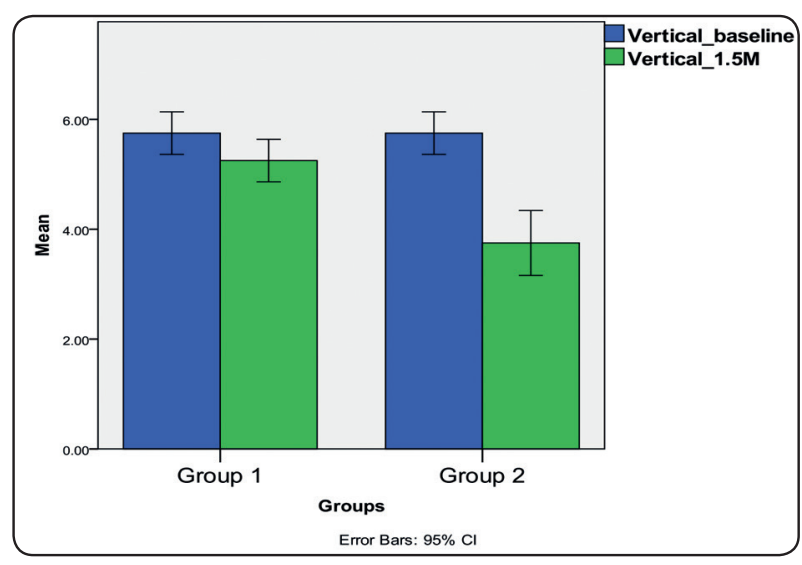

Fig. (2) Bar chart showing mean vertical graft dimension (mm) in both groups 
TABLE (2) Descriptive statistics of graft horizontal dimension $(\mathrm{mm})$, intergroup comparison (independent $t$ test) and intragroup comparisons (paired $t$ test)

\begin{tabular}{|c|c|c|c|c|c|}
\hline \multicolumn{2}{|c|}{ Groups } & \multirow{2}{*}{\begin{tabular}{|l} 
Baseline \\
12.88
\end{tabular}} & \multirow{2}{*}{$\begin{array}{l}\begin{array}{l}1.5 \\
\text { month }\end{array} \\
11.50\end{array}$} & \multirow{2}{*}{\begin{tabular}{|l|}
$\begin{array}{l}\text { Mean } \\
\text { difference }\end{array}$ \\
1.38
\end{tabular}} & \multirow{2}{*}{\begin{tabular}{|l}
$\mathbf{P}$ \\
\end{tabular}} \\
\hline \multirow{6}{*}{$\begin{array}{c}\vec{\Xi} \\
\stackrel{0}{0} \\
\dot{0}\end{array}$} & Mean & & & & \\
\hline & Std. Dev & .64 & 1.20 & & \multirow{5}{*}{$.004 *$} \\
\hline & Std. Error & .23 & .42 & & \\
\hline & Range & 2.00 & 3.00 & & \\
\hline & Min & 12.00 & 10.00 & & \\
\hline & Max & 14.00 & 13.00 & & \\
\hline \multirow{7}{*}{ 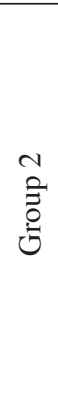 } & Mean & 13.38 & 9.63 & 3.75 & \multirow{7}{*}{$0.00 *$} \\
\hline & Std. Dev & .52 & .52 & & \\
\hline & Std. Error & .18 & .18 & & \\
\hline & Median & 13.00 & 10.00 & & \\
\hline & Range & 1.00 & 1.00 & & \\
\hline & Min & 13.00 & 9.00 & & \\
\hline & Max & 14.00 & 10.00 & & \\
\hline \multicolumn{2}{|c|}{$\begin{array}{l}\text { Intergroup } \\
\text { comparison }(\mathrm{P})\end{array}$} & $.11 \mathrm{NS}$ & $.00 *$ & & \\
\hline \multicolumn{2}{|c|}{ Mean difference } & -.50 & 1.88 & & \\
\hline \multicolumn{2}{|c|}{$\begin{array}{l}\text { Confidence } \\
\text { interval of } \\
\text { difference }\end{array}$} & $\begin{array}{l}-1.12 \\
\text { to } .12\end{array}$ & $\begin{array}{l}.84 \text { to } \\
2.91\end{array}$ & & \\
\hline
\end{tabular}

Significance level $p<0.05$, *significant, $n s=n o n$ significant

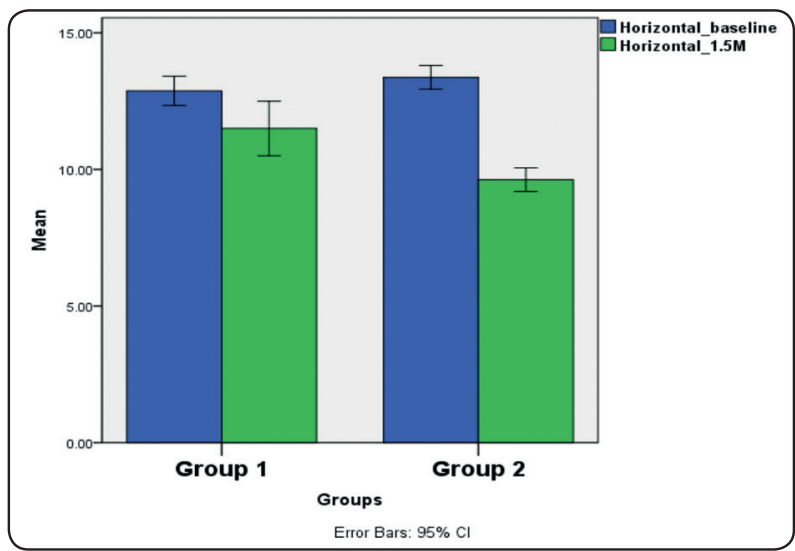

Fig. (3) Bar chart showing mean horizontal graft dimension $(\mathrm{mm})$ in both groups decreased from $(74.13 \pm 7.97)$ at baseline, to $(60.75 \pm 11.3)$ at 1.5 month. Paired $t$ test revealed that the difference between baseline and 1.5 month was statistically significant ( $\mathrm{p}=0.01$ ), (Table 3, Fig.4). In group 2, Mean value decreased from $(76.88 \pm 6.49)$ at baseline, to $(35.88 \pm 5.62)$ at 1.5 month. Paired t test revealed that the difference between baseline and 1.5 month was statistically significant ( $\mathrm{p}=0.00)$, (Table 3, Fig.4). At baseline, there was no statistically significant difference between groups ( $\mathrm{p}=0.46$ ). At 1.5 month, a higher mean value was recorded in group 1 , with a statistically significant difference $(\mathrm{p}=0.00)$, (Table 3, Fig.4)

TABLE (3) Descriptive statistics of surface area $\left(\mathrm{mm}^{2}\right)$, intergroup comparison (independent $t$ test) and intragroup comparisons (paired $t$ test)

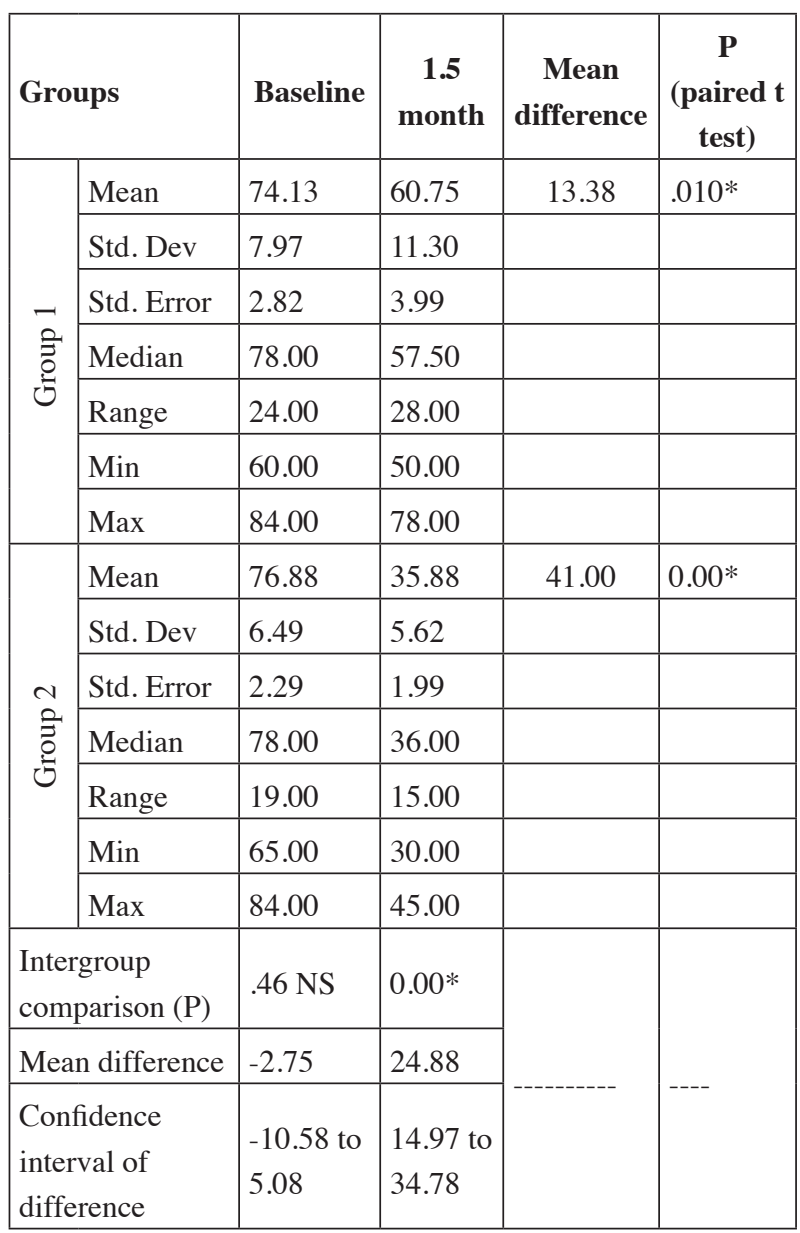




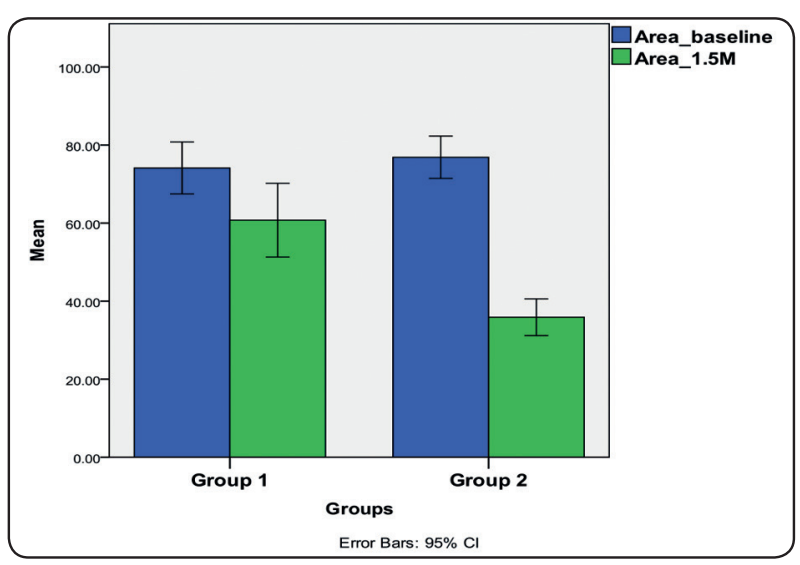

Fig. (4) Bar chart showing mean surface area $(\mathrm{mm} 2)$ in both groups

Significance level $p<0.05$, *significant, $n s=n o n$ significant

TABLE (4) Descriptive statistics of percent change (\%) and intergroup comparisons (Mann Whitney U test)

\begin{tabular}{|c|c|c|c|c|}
\hline & Groups & $\begin{array}{l}\text { Vertical } \\
\text { dimension }\end{array}$ & $\begin{array}{l}\text { Horizontal } \\
\text { dimension }\end{array}$ & $\begin{array}{c}\text { Surface } \\
\text { area }\end{array}$ \\
\hline & Median & -8.33 & -14.84 & -22.62 \\
\hline & Mean & -8.33 & -10.76 & -17.81 \\
\hline- & Std. Dev & 8.91 & 7.23 & 13.57 \\
\hline $\bar{\Xi}$ & Std. Error & 3.15 & 2.56 & 4.80 \\
\hline & Range & 16.67 & 16.67 & 30.56 \\
\hline & Min & -16.67 & -16.67 & -30.56 \\
\hline & Max & .00 & .00 & .00 \\
\hline & Median & -33.33 & -28.57 & -53.85 \\
\hline & Mean & -35.00 & -28.02 & -53.30 \\
\hline$n$ & Std. Dev & 9.43 & 3.22 & 6.31 \\
\hline $\bar{z}$ & Std. Error & 3.33 & 1.14 & 2.23 \\
\hline & Range & 33.33 & 7.69 & 21.98 \\
\hline & Min & -50.00 & -30.77 & -64.29 \\
\hline & $\operatorname{Max}$ & -16.67 & -23.08 & -42.31 \\
\hline & $\begin{array}{l}\text { Mann Whitney } \\
\text { est) }\end{array}$ & $.001 *$ & $.001 *$ & $.001 *$ \\
\hline & an difference & 26.67 & 17.26 & 35.49 \\
\hline
\end{tabular}

\begin{tabular}{|l|l|l|l|}
\hline $\begin{array}{l}\text { Confidence interval } \\
\text { of difference }\end{array}$ & $\begin{array}{l}16.83 \\
\text { to36.51 }\end{array}$ & $\begin{array}{l}11.00 \text { to } \\
23.53\end{array}$ & $\begin{array}{l}23.68 \text { to } \\
47.30\end{array}$ \\
\hline
\end{tabular}

\section{Significance level $p<0.05$, *significant}

Percent change: Regarding the graft vertical dimension; a greater mean and median percent decrease was noted in group 2. Mann Whitney U test revealed that this difference was statistically significant $(\mathrm{p}=0.001)$. Regarding the graft horizontal dimension; a greater mean and median percent decrease was noted in group 2. Mann Whitney U test revealed that this difference was statistically significant ( $\mathrm{p}=0.001)$. Regarding the graft Surface area; a greater mean and median percent decrease was noted in group 2. Mann Whitney U test revealed that this difference was statistically significant $(\mathrm{p}=0.001)$. (Table 4$)$

\section{DISCUSSION}

Many studies showed that the presence of attached gingiva is critical for the prevention of gingival recession and maintenance of healthy periodontium (Lang \& Loe, 1972). The free gingival graft (FGG) is a gingival augmentation technique introduced many years ago to increase the keratinized gingiva (H.B. 1963, Sullivan \&Atkins, 1968, Agudio et al., 2008), but many studies proved that the FGG showed changes in the graft horizontal dimension (GHD), graft vertical dimension (GVD) and graft surface area (GSA) overtime after grafting and specially during the first postoperative month ( Ericsson \&Lindhe, 1984, Hatipoglu et al., 2007). This study was carried to evaluate the effect of the placement of PRF membrane beneath the free gingival graft in gingival augmentation surgeries regarding the changes over time in graft's horizontal dimension, vertical dimension and surface area.

All the patients selected were of thin gingival biotype since studies showed that thin biotype is more commonly associated with narrow attached gingiva ( Olsson et al.,1993, Anderegg et al., 1995, 
Baldi et al.,1999, Gobbato et al., 2012) . Patients with crowding, subgingival restorations or who didn't follow the plaque control instructions after conventional periodontal treatment were excluded from the study to avoid the effect of any local predisposing factors on the final results.

The FGG was harvested from the palate between the palatal root of the first molar and the distal line angle of the canine where the thickest tissue is usually available (Reiser et al., 1996). The submucosa of the anterior palate is rich in fat ( Orban 1996), thus after graft harvesting curved scissors was used to remove any fatty tissue from the connective tissue surface of the graft to obtain a uniform graft thickness around $1.5 \mathrm{~mm}$ thickness before suturing at the recipient site to allow quick graft revascularization.

A small piece of the PRF membrane was used to cover the wound at the donor site stabilized by horizontal mattress suture as a recent study reported that PRF significantly accelerated the palatal wound healing after graft harvesting and reduced donor site morbidity. (Femminella et al., 2016) .

A follow up of 1.5 month was selected in our study since previous studies showed that the main change in transplanted tissue dimensions occurred during the first month. (Ericsson \&Lindhe, 1984, Hatipoglu et al., 2007). Also literature showed that the FGG shrinkage between baseline and first month is statistically more significant than shrinkage between first and third month. Also the gain in keratinized gingiva after grafting is significant from zero to one month and not significant from one to three months. (Cifsibasi et al., 2015)

The same median baseline PD, BI, PI values were recorded in both groups, with no significant difference. In both groups, no significant difference between baseline and 1.5 month values of PD, BI, PI. Thus, the patient oral hygiene and the plaque control can be excluded to have any effects on the final study results.
Regarding the baseline GVD; there was no statistically significant difference between the groups. Also no statistically significant difference was found between the groups regarding the baseline GHD. This was since all the cases in this study were of two mandibular incisors with insufficient attached gingiva thus nearly similar grafts dimensions were required in all cases.

In both groups, the mean value of GVD decreased significantly 1.5 month after the surgery and the same results were obtained with the GHD and the GSA. This was in accordance with the previous literature that proved that transplanted FGG showed significant changes in the horizontal and vertical dimensions overtime after grafting and specially in the first postoperative month (( Ericsson \&Lindhe, 1984, James \& Mc Fall, 1978, Orsini et al., 2004 Hatipoglu et al., 2007, Hatipoglu et al., 2007, Barbosa et al., 2009)

In Group 2 (FGG alone) the mean percent decrease in GVD was $35 \%$ which was in accordance with previous clinical studies that showed vertical shrinkage of FGG percentage from $31 \%$ to $45 \%$ ( Ward, 1974, Silva et al., 2010, Barbosa et al., 2009 ). Other studies reported less shrinkage of $16.6 \%$ $-22.4 \%$ ( Guncu et al., 2012)

Regarding the GHD shrinkage, the mean percent decrease in group 2 was $28.02 \%$ at 1.5 month while previous study by Silva et al 2010 reported $17 \%$ and $22 \%$ mean percent decrease in GHD at 30 and 90 days respectively (Silva et al., 2010). Another study by Hatipoglu et al reported $5.8 \%$ and $10.2 \%$ percent decrease in GHD at day 21 and day 180 respectively while Guncu et al showed $9.8 \%$ and $14.25 \%$ decrease at day 21 and 180 respectively (Hatipoglu et al., 2007, Guncu et al., 2012).

Regarding the graft surface area (GSA) obtained by multiplying the horizontal and vertical dimensions, the mean decrease in GSA in group 2 was $53.3 \%$.Other studies evaluated the change in GSA, one showed $37 \%$ mean percent decrease in 
GSA in 1 month period (Silva et al 2010) and the other showed $23.8 \%$ and $32.1 \%$ decrease in 21 days and 180 days recpectively (Hatipoglu et al., 2007).

Regarding Group 1 (Test group; FGG combined with PRF) the mean percent decrease in GVD was $8.33 \%$, GHD was $10.76 \%$ \& surface area was $17.81 \%$. To the best of our knowledge no previous studies tested the graft dimensional changes when FGG is combined with PRF.

Regarding the percent of change in GVD, greater mean and median percent decrease was noticed in group 2 and on comparing both groups statistically significant difference was found. The same was obtained with GHD and GSA. This means that group 1 ( FGG +PRF) showed significant less shrinkage of the graft which may be related to the PRF used beneath the graft. To the best of our knowledge, no previous studies compared FGG alone to FGG combined with PRF.

Literature studying the healing of FGG showed that in the first days after surgery, the grafted tissues survive with the plasmatic circulation from the recipient bed, before anastomosis between the blood vessels of the recipient bed and the grafted tissue which occurs 4-5 days after surgery. This is followed by capillaries proliferation and fibrous union between the graft and underlying connective tissue.(Oliver et al 1968, Nobuta et al 1988)

Taking in consideration that PRF is rich in platelets, leukocytes and growth factors, this directly promote the proliferation of endothelial cells and fibroblasts (He et al., 2009, Dohan Ehrenfest et al., 2009, Carlson \& Roach, 2002, Roy et al., 2011, Chen et al., 2011, Toffler et al., 2009). This may help in accelerating the anastomosis and proliferation of new capillaries thus promoting rapid tissue repair and descrease the shrinkage of the transplanted tissue. Also the sticky nature of PRF helps in stabilization of the graft which is essential to achieve therapeutic success. (Whitman et al.,1997, Vikov et al., 2005). Moreover, the leukocytes within the PRF helps to eliminates any pathogens at the wound after surgery thus decrease the bacterial contamination so promoting direct healing and may minimizes the graft shrinkage (Clark, 2001).

\section{CONCLUSION}

Using platelet-rich fibrin beneath free gingival graft in gingival augmentation surgery resulted in successful increase in the attached gingiva with less dimensional changes in the transplanted free gingival graft compared to using free gingival graft alone. Further studies should be carried to additionaly explain the results obtained and to study the histological structure of the obtained grafted tissues by the two modalities.

\section{REFERENCES}

1. Agudio G, Nieri M, Rotundo R, Cortellini P, Pini Prato G. Free gingival grafts to increase keratinized tissue: A retrospective long-term evaluation (10 to 25 years) of outcomes. J Periodontol;79:587-594. 2008

2. Agudio G, Nieri M, Rotundo R, Franceschi D, Cortellini P, Pini Prato GP. Periodontal conditions of sites treated with gingival-augmentation surgery compared to untreated contralateral homologous sites: A 10- to 27-year long-term study. J Periodontol;80:1399-1405. 2009

3. Alain Simonpieri, Marco Del Corso, Gilberto Sammartino, David M., Dohan Ehrenfest. The Relevance of Choukroun's Platelet-Rich Fibrin and Metronidazole during Complex Maxillary Rehabilitations using Bone Allograft. Part II: Implant Surgery, Prosthodontics, and Survival. Implant dentistry .18: 3. 2009.

4. Anfossi G, Trovati M, Mularoni E, Massucco P, Calcamuggi G, Emanuelli G .Influence of propranolol on platelet aggregation and thromboxane $\mathrm{B} 2$ production from platelet-rich plasma and whole blood. Prostaglandins Leukot Essent Fat Acids 36:1-7. 1989

5. Anderegg CR, Metzler DG, Nicoll BK. Gingiva thickness in guided tissue regeneration and associated recession at facial furcation defects. J Periodontol;66:397- 402. 1995

6. Andrades JA, Han B, Becerra J, Sorgente N, Hall FL, Nimni ME A recombinant human TGF-betal fusion protein with collagen-binding domain promotes migration, growth, and differentiation of bone marrow mesenchymal cells. Exp Cell Res 250: 485-498. 1999 
7. Baldi C, Pini-Prato G, Pagliaro U, et al. Coronally advanced flap procedure for root coverage. Is flap thickness a relevant predictor to achieve root coverage? A 19-case series. J Periodontol;70:1077-1084. 1999

8. Barbosa FI, Correa DS, Zeno bio EG, Costa FO, Shibli JA. Dimensional changes between free gingival grafts fixed with ethyl cyanoacrylate and silk sutures. J Int Acad Periodontol;11:170-176. 2009

9. Barriviera M, Duarte WR, Januario AL, Faber J, Bezerra AC. A new method to assess and measure palatal masticatory mucosa by cone-beam computerized tomography. J Clin Periodontol;36:564-568. 2009

10. Brackett RC, Gargiulo AW. Free gingival grafts in humans. J Periodontol;41:581-586. 1970

11. Bjorn, H. Free transplantation of gingiva propria. Svensk Tandlakare Tidskrift 22, 684-685. 1963

12. Breault, L.G., Fowler, E.B., \& Billman, M.A. Retained free gingival graft rugae: A 9-year case report. Journal of Periodontology. 70: 438-440. 1999

13. Camargo PM, Melnick PR, Kenney EB. The use of free gingival grafts for aesthetic purposes. Periodontol 2000;27:72-96. 2001

14. Carlson NE, Roach RB Jr Platelet-rich plasma: clinical applications in dentistry. J Am Dent Assoc 1939(133):1383-1386. 2002

15. Carranza FA Jr., Carroro JJ, Albano E. Mucogingival surgery. In: Stahl SS, ed. Periodontal Surgery: Biologic Basis and Technique. Springfield, IL: Charles C. Thomas; 1976.

16. Choukroun J, Adda F, Schoeffler C. Une opportunite en paroimplantologie: le PRF. Implantodontie.,42:55-62. 2001

17. Choukroun J, Diss A, Simonpieri A. Platelet-rich fibrin (PRF): A second generation platelet concentrate. Part IV. Clinical effects on tissue healing. Oral Surg Oral Med Oral Pathol Oral Radiol Endod.;101:e56-e60. 2006

18. Choukroun J, Diss A, Simonpieri A. Platelet-rich fibrin (PRF): A second generation platelet concentrate. Part V. Histologic evaluations of PRF effects on bone allograft maturation in sinus lift. Oral Surg Oral Med Oral Pathol Oral Radiol Endod.;101:299-303. 2006

19. Clark RA Fibrin and wound healing. Ann N Y Acad Sci 936:355-367. 2001
20. Cohen, E.S. Atlas of Cosmetic and Reconstructive Periodontal Surgery. Philadelphia: Lea and Febiger. 1994

21. Corso M Del, Toffler M, Dohan Ehrenfest DM. Use of an Autologous Leukocyte and Platelet-Rich Fibrin (L-PRF) membrane in Post-avulsion Sites. An Overview of Choukroun's PRF. J Implant Adv Clin Dent 1(9): 27-35. 2010

22. Davis, J.S., \& Traut, H.F. Origin and development of the blood supply of whole-thickness skin grafts. Annals of Surgery. 82: 871-879. 1925

23. David M. Kim , Rodrigo Neiva. Periodontal Soft Tissue Non-Root Coverage Procedures: A Systematic Review From the AAP Regeneration Workshop J Periodontol . 86:2 (Suppl.) 2015

24. De Rouck T, Eghbali R, Collys K, De Bruyn H, Cosyn J. The gingival biotype revisited: Transparency of the periodontal probe through the gingival margin as a method to discriminate thin from thick gingiva. J Clin Periodontol;36:428-433. 2009

25. Diss A, Dohan DM, Mouhyi J, et al. Osteotome sinus floor elevation using Choukroun's platelet-rich fibrin as grafting material: A 1-year prospective pilot study with microthreaded implants. Oral Surg

26. Oral Med Oral Pathol Oral Radiol Endod.;105:572-579. 2008

27. Dohan DM, Choukroun J, Diss A, et al. Platelet-rich fibrin (PRF): A second generation platelet concentrate. Part I. Technological concepts and evolution. Oral Surg Oral Med Oral Pathol Oral Radiol Endod.;101:e37-e44. 2006

28. Dohan DM, Choukroun J, Diss A, et al. Platelet-rich fibrin (PRF): A second generation platelet concentrate. Part II. Platelet-related biologic features. Oral Surg Oral Med Oral Pathol Oral Radiol Endod.;101:e45-e50. 2006

29. Dohan DM, Choukroun J, Diss A, et al. Platelet-rich fibrin (PRF): A second generation platelet concentrate. Part III. Leucocyte activation: a new feature for platelet concentrates? Oral Surg Oral Med Oral Pathol Oral Radiol Endod.;101: e51-e55. 2006

30. Dohan Ehrenfest DM, Del Corso M, Diss A, Mouhyi J, Charrier JB .Three-dimensional architecture and cell composition of a Choukroun's platelet-rich fibrin clot and membrane. J Periodontol 81:546-555. 2010

31. Dohan Ehrenfest DM, Diss A, Odin G, Doglioli P, Hippolyte MP, Charrier JB. In vitro effects of Choukroun's 
PRF (plateletrich fibrin) on human gingival fibroblasts, dermaprekeratinocytes, preadipocytes, and maxillofacial osteoblasts inprimary cultures. Oral Surg, Oral Med, Oral Pathol, Oral Radiol Endod 108:341-352. 2009

32. Dohan Ehrenfest DM, Pinto NR, Pereda A. The impact of the centrifuge characteristics and centrifugation protocols on the cells, growth factors, and fibrin architecture of a leukocyte- and platelet-rich fibrin (L-PRF) clot and membrane. Platelets 29 (2): 171-184. 2018

33. Dorfman HS, Kennedy JE, Bird WC. Longitudinal evaluation of free autogenous gingival grafts. J Clin Periodontol;7:316-324. 1980

34. Dorfman HS, Kennedy JE, Bird WC. Longitudinal evaluation of free autogenous gingival grafts. A four year report. J Periodontol;53:349-352. 1982

35. Dreeskamp M, de Jacoby LF. Breadth of the gingiva propria in vestibuloplasty following gingiva transplantation. Dtsch Zahnarztl Z;28: 192-197. 1973

36. Eghbali A, De Rouck T, De Bruyn H, Cosyn J. The gingival biotype assessed by experienced and inexperienced clinicians. J Clin Periodontol;36:958- 963. 2009

37. Egli U, Vollmer WH, Rateitschak KH. Follow-up studies of free gingival grafts.JClinPeriodontol;2:98-104. 1975

38. Ellegaard, B., Karring, T., \& Loe, H. New periodontal attachment procedure based on retardation of epithelial migration. Journal of Clinical Periodontology. 1: 75-88. 1974

39. Emine Cifcibaşi, Volkan Karabey, Cenker koyuncuoğlu, Ezgi Düzağaç, Emrah Genceli, Kamber Kasali, Serdar Cintan. Clinical evaluation of free gingival graft shrinkage in horizontal and vertical dimensions. J Istanbul Univ Fac Dent. 49(3):11-16. 2015

40. Ericsson I, Lindhe J. Recession in sites with inadequate width of the keratinized gingiva. An experimental study in the dog. J Clin Periodontol;11(2):95-103. 1984

41. Fijnheer R, Pietersz RN, de Korte D, Gouwerok CW, DekkerWJ, ReesinkHW, RoosD . Platelet activation during preparation of platelet concentrates: a comparison of the platelet-rich plasma and the buffy coat methods. Transfusion 30:634-638. 1990

42. Foman, S. Cosmetic Surgery. Philadelphia: Lippincott. 1960

43. Freedman AL, Green K, Salkin LM, Stein MD, Mellado JR. An 18-year longitudinal study of untreated mucogingival defects. J Periodontol;70:1174-1176. 1999
44. Gargiulo AW, Wentz FM, Orban B. Dimensions and relations of the dentogingival junction in humans. J Periodontol;32:261-267. 1961

45. Glavind L, Loe H: Erras in the clinical assessment of periodontal destruction. J Periodont Res; 2:180. 1967

46. Glavind L, Loe H: Erras in the clinical assessment of periodontal destruction. J Periodont Res; 2:180. 1967

47. Glick M, Greenberg MS, Ship JA. Introduction to Oral Medicine and Oral Diagnosis: Evaluation of the dental patient. In Burket s oral medicine. eleventh ed. Bc decker inc. Hamilton, 1-16. 2008

48. Gobbato L, Tsukiyama T, Levi PA Jr, Griffin TJ, Weisgold AS. Analysis of the shapes of maxillary central incisors in a Caucasian population. Int J Periodontics Restorative Dent;32:69-78. 2012

49. Goldman HM, Isenberg G, Shuman A. The gingival autograft and gingivectomy. J Periodontol;47: 586-589. 1976

50. Greenberg J, Laster L, Listgarten MA. Transgingival probing as a potential estimator of alveolar bone level. J Periodontol;47:514-517. 1976

51. Hideo Masuki, Toshimitsu Okudera, Taisuke Watanebe, Masashi Suzuki, Kazuhiko Nishiyama, Hajime Okudera, Koh Nakata, Kohya Uematsu, Chen-Yao $\mathrm{Su}$ and Tomoyuki Kawase . Growth factor and pro-inflammatory cytokine contents in platelet-rich plasma (PRP), plasma rich in growth factors (PRGF), advanced platelet-rich fibrin (A-PRF), and concentrated growth factors (CGF). International Journal of Implant Dentistry 2:19. 2016

52. Guncu GN KH, Ercan E, Hatipoglu H, Ilhan D, Tozum TF. Vertical and horizontal dimensional evaluation of sutureless free gingival grafts. . Clin Dent Res;36(2):2935. 2012

53. H. B. Free transplantation of gingiva propria. . Swed Dent J;22: 684-689. 1963

54. Hatipoglu H, Kecxeli HG, Guncu GN, Sengun D, Tozum TF. Vertical and horizontal dimensional evaluation of free gingival grafts in the anterior mandible: A case report series. Clin Oral Investig;11: 107-113. 2007

55. He L, Lin Y, Hu X, Zhang Y,Wu H .A comparative study of platelet-rich fibrin (PRF) and platelet-rich plasma (PRP) on the effect of proliferation and differentiation of rat osteoblasts in vitro. Oral Surg, Oral Med, Oral Pathol, Oral Radiol Endod 108:707-713. 2009 
56. Hwang D, Wang HL. Flap thickness as a predictor of root coverage: A systematic review. J Periodontol ;77:16251634. 2006

57. Holbrook, T., \& Ochsenbein, C. Complete coverage of the denuded root surface with a one stage gingival graft. International Journal of Periodontics and Restorative Dentistry. 3(3): 9-27. 1983

58. Jameson C .Autologous platelet concentrate for the production of platelet gel. Lab Med 38:39-42. 2007

59. James WC, McFall WT. Placement of free gingival grafts on denuded alveolar bone. Part I: Clinical evaluations. J Periodontol;49:283-290. 1978

60. Kang YH, Jeon SH, Park JY, Chung JH, Choung YH, Choung HW, Kim ES, Choung PH . Platelet-rich fibrin is a bioscaffold and reservoir of growth factors for tissue regeneration. Tissue Eng A 17:349-359. 2011

61. Kawase T, Okuda K, Wolff LF, et al. Platelet-rich plasmaderived fibrin clot formation stimulates collagen synthesis in periodontal ligament and osteoblastic cells in vitro. $\mathrm{J}$ Periodontol.;74:858-864. 2003

62. Kennedy JE, Bird WC, Palcanis KG, Dorfman HS. A longitudinal evaluation of varying widths of attached gingiva. J Clin Periodontol;12:667-675. 1985

63. Kisch J, Badersten A, Egelberg J. Longitudinal observation of "unattached," mobile gingival areas. J Clin Periodontol;13:131-134. 1986

64. Kobayashi E, Fluckiger L, Fujioka-Kobayashi M, Sawada K, Sculean A, Schaller B, Miron RJ. Comparative release of growth factors from PRP, PRF, and advanced-PRF. Clin Oral Investig. 2016

65. Kutkut, A., Andreana, S.. Extraction socket preservation graft before implant placement with calcium sulfate hemihydrate and platelet-rich plasma: a clinical and histomorphometric study in humans. J. Periodontol. 83 (4), 401-409. 2012

66. Lampert F, Lange DE, Flores de Jacoby L. Free mucosal transplantations. Dtsch Zahnarztl Z;31:367-370. 1976

67. Lang NP, Loe H. The relationship between the width of keratinized gingiva and gingival health. J Periodontol 43:623-627. 1972

68. Lindhe J, Marynard G Jr., Miller PD, et al. Consensus report. Mucogingival therapy. Ann Periodontol;1: 702-706. 1996

69. Lindeboom JA, Mathura KR, Aartman IH, et al. Influence of the application of platelet-enriched plasma in oral mucosal wound healing. Clin Oral Implants Res.;18:133139. 2007

70. Loe H. The gingival index, plaque index, retention index system. J Periodontol. 38:61. 1967

71. Marx RE, Carlson ER, Eichstaedt RM, Schimmele SR, Strauss JE, Georgeff KR Platelet-rich plasma: growth factor enhancement for bone grafts. Oral Surg Oral Med Oral Pathol Oral Radiol Endod 85:638-646. 1998

72. Marx RE .Platelet-rich plasma: evidence to support its use. J Oral Maxillofac Surg 62:489-496. 2004

73. Miller, P.D. Root coverage using the free soft tissue autograft following citric acid application. III. A successful and predictable procedure in areas of deep wide recession. International Journal of Periodontics and Restorative Dentistry 5(2): 15-37. 1985

74. Miller, P.D. A classification of marginal tissue recession. International journal of periodontics and restorative dentistry; 5(2)9-13. 1985

75. Muhlemann HR, Son S: Gingival sulcus bleeding. A leading symptom in initial gingivitis. Helv Odontol Acta; 15:107. 1971

76. Muller HP, Schaller N, Eger T, Heinecke A. Thickness of masticatory mucosa. J Clin Periodontol;27:431- 436. 2000

77. Neha Joshi, Manvi Chandra Agarwal, Ellora Madan, Shubhangi Gupta, Aditya Law. Gingival Biotype and Gingival Bioform: Determining Factors for Periodontal Disease Progression and Treatment Outcome . International Journal of Scientific Study; 4 :3 . 2016

78. Nevins M. Attached gingiva - Mucogingival therapy and restorative dentistry. Int $\mathbf{J}$ Periodontics Restorative Dent;6(4):9-27. 1986

79. Nobuto T, Imai H, Yamaoka A. Microvascularization of free gingival autograft. Journal of periodontology; 59:639646. 1988

80. Oliver RG, Loe H, Karring T . Microscopic evaluation of the healimg and revascularization of free gingival grafts . Journal of periodontal research ;3:84-95.1986

81. Olsson M, Lindhe J, Marinello CP. On the relationship between crown form and clinical features of the gingiva in adolescents. J Clin Periodontol;20:570-7. 1993

82. Orsini M, Orsini G, Benlloch D, Aranda JJ, Lazaro P, Sanz $\mathrm{M}$. Esthetic and dimensional evaluation of free connective 
tissue grafts in prosthetically treated patients: A 1-year clinical study. J Periodontol;75: 470-477. 2004

83. Pontoriero R, Carnevale G. Surgical crown lengthening: A 12-month clinical wound healing study. J Periodontol; 72:841-848. 2001

84. Rateitschak KH, Egli U, Fringeli G. Recession: A 4-year longitudinal study after free gingival grafts. J Clin Periodontol;6:158-164. 1979

85. Reese, JD, Stark, RB. Principles of free skin grafting. Bulletin of New York Academy of Medicine (Ser 2) 37, 213. 1961

86. Reiser, G.M., Bruno, J.F., Mahan, P.E., \& Larkin, L.H. The subepithelial connective tissue graft palatal donor site: Anatomic considerations for surgeons. International Journal of Periodontics and Restorative Dentistry 16131-137. 1996

87. Salkin LM, Freedman AL, Stein MD, Bassiouny MA. A longitudinal study of untreated mucogingival defects. J Periodontol;58:164-166. 1987

88. Silva CO, Ribeiro Edel P, Sallum AW, Tatakis DN. Free gingival grafts: Graft shrinkage and donor-site healing in smokers and non-smokers. J Periodontol;81(5):692-701. 2010

89. Soehren SE, Allen AL, Cutright DE, Seibert JS. Clinical and histologic studies of donor tissues utilized for free grafts of masticatory mucosa. J Periodontol;44: 727-741. 1973

90. Stein JM, Lintel-Ho“ping N, Hamma“cher C, Kasaj A, Tamm M, Hanisch O. The gingival biotype: Measurement of soft and hard tissue dimensions - A radiographic morphometric study. J Clin Periodontol; 40:1132-1139. 2013

91. Stetler KJ, Bissada NF. Significance of the width of keratinized gingiva on the periodontal status of teeth with submarginal restorations. J Periodontol;58: 696-700. 1987

92. Sullivan HC, Atkins JH. Free autogenous gingival grafts. I. Principles of successful grafting. Periodontics; 6:121-129. 1968

93. Sullivan HC, Atkins JH. Free autogenous gingival grafts. 3. Utilization of grafts in the treatment of gingival recession. Periodontics;6:152-160. 1968
94. Toffler M, Toscano N, Holtzclaw D, Corso M, Dohan D. Introducing Choukroun's platelet rich fibrin (PRF) to the reconstructive surgery milieu. J Implant Adv Clin Dent $1: 22-31.2009$

95. van Hinsbergh VW, Collen A, Koolwijk P. Role of fibrin matrix in angiogenesis. Ann N Y Acad Sci.;936:426-437. 2001

96. Vitkov L, Krautgartner WD, Hannig M. Surfacemorphology of pocket epithelium. Ultrastruct Pathol. 29(2):121127. 2005

97. Wara-aswapati N, Pitiphat W, Chandrapho N, Rattanayatikul C, Karimbux N. Thickness of palatal masticatory mucosa associated with age. Journal of periodontology. 72(10):1407-12. 2001

98. Ward VJ. A clinical assessment of the use of the free gingival graft for correcting localized recession associated with frenal pull. J Periodontol;45: 78-83. 1974

99. Weisgold AS. Contours of the full crown restoration. Alpha Omegan;70:77-89. 1977

100. Wennstrom JL. Lack of association between width of attached gingiva and development of soft tissue recession. A 5-year longitudinal study. J Clin Periodontol;14:181-184. 1987

101. Wennstrom J, Lindhe J, Nyman S. Role of keratinized gingiva for gingival health. Clinical and histologic study of normal and regenerated gingival tissue in dogs. J Clin Periodontol;8:311-328. 1981

102. Wennström J, Lindhe J. Role of attached gingiva for maintenance of periodontal health. Healing following excisional and grafting procedures in dogs. J Clin Periodontol;10:206-21. 1983

103. Whitman DH, Berry RL, Green DM .Platelet gel: an autologous alternative to fibrin glue with applications in oral and maxillofacial surgery. J Oral Maxillofac Surg 55:1294-1299. 1997

104. Wilson RD. Marginal tissue recession in general dental practice: A preliminary study. Int $\mathrm{J}$ Periodontics Restorative Dent; 3(1):40-53. 1983 